\title{
The complementarities of big data and intellectual capital on sustainable value creation; collective intelligence approach
}

\author{
Raazia Gul $^{1}$ - Nazima Ellahi ${ }^{2} \cdot$ Mamdouh Abdulaziz Saleh Al-Faryan $^{3,4}$
}

Accepted: 29 September 2021

(c) The Author(s), under exclusive licence to Springer Science+Business Media, LLC, part of Springer Nature 2021

\begin{abstract}
It is evident in the literature that both intellectual capital and big data analytics create value to the organizations independently, but how threats, opportunities, capabilities and value creation for intellectual capital change with big data adoption is largely unexplored. This paper aims to develop an analytical framework for identifying challenges, opportunities, capabilities and value creation in the face of complementarity between big data and components of intellectual capital. The paper uses a Collective Intelligence approach as a theoretical background. Based on Structured Literature Review, the current study has developed an analytical framework for organizations to be used as a decision-making tool while making investment in big data and managing intellectual capital. Findings suggest that the scope of human capital has changed largely as now employees are expected much more than in the past with strong analytical, dynamic, technical and IT capabilities. Structural capital calls for new practices, routines and procedures to be adopted and old methods to unlearn whereas relational capital stresses the importance of network building and social media to create sustainable value for the society.
\end{abstract}

Keywords Big data - Intellectual capital · Collective intelligence · Value creation · Intangible knowledge assets · Structured literature review

\section{Introduction}

Big data (BD) is widely studied as an emerging knowledge asset across the world. Big data refers to high volume, high-velocity and high-variety data (Laney, 2001). Fundamentally, big data does not hold any value unless analytics, skills, and tools are used to draw insight and

Raazia Gul

raazigul@gmail.com

1 Department of Business Administration, Foundation University, Islamabad, Pakistan

2 Department of Economics \& Finance, Foundation University, Islamabad, Pakistan

3 Department of Economics and Finance, Faculty of Business and Law, University of Portsmouth, Portsmouth, UK

4 Consultant in Economics and Finance, Riyadh, Saudi Arabia 
extract value to an organization (Secundo et al., 2017). It needs resources, including humans, processes and structures, and networks to create value. Therefore, the need to understand managerial implications regarding translating big data into organizational value in the form of intellectual capital (IC) is increasing. IC is also an intangible knowledge asset which is based on human, relational and structural resources known as human capital (HC), relational capital (RC), and structural capital (SC) respectively. It is well documented in the literature that higher intellectual capital positively impacts the firms' value creation and financial performance (de Santis \& Presti, 2018; Secundo et al., 2017). However, with the emergence of big data, the scope of IC is changing (Gandomi \& Haider, 2015; Martin-Moncunill et al., 2016; Secundo et al., 2017).

Since data provides an insight into the information when converted into organizational value, big data's value to IC lies in a firm's ability to transform massive data into an insight useful in decision making (La Torre et al., 2018a, 2018b; Secundo et al., 2017). Big data offers a bridge between inside knowledge assets known as human and structural capital and outside knowledge assets known as relational capital (Erickson \& Rothberg, 2015).

Although few scholars have started realizing the need to integrate big data analytics at the fourth stage of intellectual capital (Erickson \& Rothberg, 2015; Gao et al., 2020; Fredriksson, 2015; Secundo et al., 2017; de Santis \& Presti, 2018; Uden, 2018), the research is still at a conceptual stage. Moreover, most of the research on big data analytics focuses on creating value for a firm. Big data analytics is the use of progressive analytic techniques to very large, heterogeneous data sets, which can contain structured, semi-structured, and unstructured data, as well as data from many sources and sizes ranging from terabytes to zettabytes. In contrast, few scholars have pointed out how that value can be created and how scope of IC in terms of threats and challenges changes with the adoption of big data (Secundo et al., 2017). Therefore, it requires more in-depth insight into how BD and IC co-create value in an organization for wider society.

Nonetheless, BD and IC's value creation potential could only be exploited if a company has the required expertise, tools, skills, and knowledge. When organizations collaborate that knowledge through shared vision and expertise of major stakeholders involved, it is called collective intelligence (Barón et al., 2018; Malone et al., 2010). The Collective Intelligence Framework is a system for managing cyber-threat intelligence. It enables you to integrate known harmful threat information from a variety of sources and use it for incident response, detection (IDS), and mitigation. The method by which large amount of group collect and exchange their knowledge, data, and skills in order to solve social problems is known as collective intelligence. It has the superior capacity formed when distributed individuals work together with the technology assistance to gather new insights, ideas and information to solve an issue. Therefore, the purpose of this study is to explore how big data and intellectual capital co-create value in an organization from a collective intelligence perspective. Since the topic is emerging and literature is scant, we adopted structured literature review (SLR) to explore the complementarities of big data and intellectual capital from value creation perspective, and developed following three questions to answer in this study following Massaro et al., (2016).

Question 1: How is the research on the complementarity of BD and components of IC developing from value creation perspective?

Question 2: What is the criteria and focus of the research on the complementarity of BD and IC?

Question 3: what is the future for the research on the complementarity of BD \& IC? 


\section{Material and methods}

Both intellectual capital and big data analytics create value to the organizations, where big data adoption is largely unexplored, so the main motive of this paper is to develop an analytical framework between big data and intellectual capital components. However, the Collective Intelligence and Structured Literature Review is used as a theoretical background in managing intellectual capital and suggest that human capital has changed largely. This study aims to answer the main research question: how the complementarities of big data and intellectual capital co-create value in an organization? Since the idea is novel and the literature is scant, the best way to investigate how big data and intellectual capital co-create value in an organization would be possible through an inductive approach. For this, it is decided to develop an analytical framework based on structured literature review to gain an insight into the complementarities of big data and intellectual capital. SLR is regarded as the most effective sort of academic review for addressing and studying a specific subject before providing an informative yet critical interpretation (Massaro et al., 2016). A systematic literature review (SLR), sometimes known as a systematic review, is an approach for recognizing, assessing, and summarizing the state-of-the-art in a certain field. Furthermore, SLR restricts gathering of data from databases, allowing for a more unbiased study than standard reviews. It entails devising a well-thought-out search strategy that focuses on a certain topic or answers a specific query. SLR allows replicability of the study as it follows a rigid set of rules. Moreover, new research cannot be conducted in a vacuum; instead, it should be connected to the past research. The current study conducts a SLR to extract the most salient learnings that emerged from the past research and uncover the conceptual articulations used to bring them forward. As a result, the fundamental accomplishments and drawbacks of effectuation research are presented in a framework with respect to the guidelines provided by Massaro et al. (2016). We then make additional recommendations for future research based on our findings.

\subsection{Research approach}

Big data is an arena that deals with methods for analyzing, methodically extracting data from, then dealing with data volumes that are too great or complicated for typical dataprocessing software to handle. Internet click-stream data, Web server logs, social network movement information, social media content, survey replies, text from customer communications, machine information caught by devices and associated to IoT and mobile phone call aspect accounts are all examples of this. Big data and intellectual capital are knowledge assets and have been studied separately under different theoretical backgrounds such as Knowledge-Based View, Resource-Based View, Information Processing View, etc. However, how they both co-create value in an organization calls for a more comprehensive approach namely collective intelligence approach. The concept of Collective Intelligence developed in 1970s, though refined in late 1990 (Galiveeti et al., 2021; Lévy, 1994; Malone et al., 2008). Collective Intelligence is the ability of a group or community to solve a problem or carry out a task more efficiently and effectively through knowledge sharing and collaboration than problem-solving individually (Malone et al., 2008, 2010). Recently, Malone and Bernstein defined collective intelligence as a group of individuals working together that seems intelligent (2015). Collective intelligence is a shared vision obtained through competition and collaboration of individuals or groups who might be of different viewpoints but get along to reach a collective goal (Mulgan, 2012; Hiremath et al., 2019). 


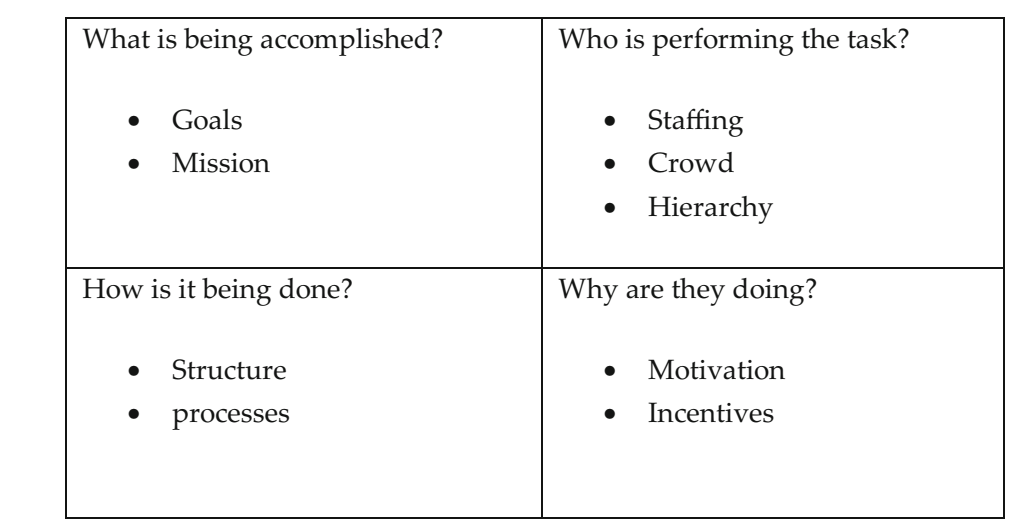

Source: Melone et al. (2010)

Fig. 1 Building blocks or "genes" of Genome Model of Collective Intelligence

Employing an analogy from biology where the genes define individuals' organisms, collective intelligence systems' genes are the core element where the whole collective intelligence system stands. A genome is an organism's complete set of genetic information, which is stored in DNA molecules called chromosomes. GEMs (genome-scale metabolic models) depict gene-protein-reaction relationships for complete metabolic genes in a being computationally and replicated to estimate metabolic fluxes for several metabolic systems-level. The huge number of genes with unidentified functions are recognized as possible roles in the genome-scale phenotypic. The whole collection of genes in a specific collective intelligence system is referred to as the "genome of that system" by Melone et al. (2010). Thus, the genome of the collective intelligence system is built around four questions: what is being done, who is doing it, why it is being done, and how it is being done. The genome of the collective intelligence system known as MIT's Genoma model' is illustrated below in Fig. 1.

The first gene of CI is "What," which is the organization's mission or goals to be achieved (Secundo et al., 2016). The CI genome's second gene is "Who"; people are involved in achieving mission and goals. The third gene is "Why," the motivation behind the actions. The motivation can be financial such as bonus, and non-financial such as love, glory, and intrinsic recognition (Secundo et al., 2016). The fourth gene is "How," the structure and processes to follow to achieve these goals (Malone et al., 2010).

\subsection{Literature search}

The first step in literature search under SLR is to identify and select relevant material as not all contributions are of equal importance and validity (Dixon-Woods, 2011). There are different techniques for literature search including citation classics, keyword search, single journal analysis, and emerging themes (Massaro et al., 2016, p.779). However, a widely referenced work is referred to as a "citation classic." A keyword search looks for certain words across the material. When you don't know the typical topic header, keyword searches are a decent substitute for a subject search. When you have insufficient title or author information, a keyword search might be used instead of a title or author search. A rhetorical examination of a specific humanities journal's customs, language, readership, goal, and content, as well as an analysis of one essay from the journal of your choice. Emergent themes are formed from 
the lifeworlds of research participants through the process of coding and are a core building element of inductive approaches to qualitative social science research. Because the debate over the BD-IC nexus is still in its early phases, and there is little literature on the subject, we employed 'keyword search' method, most suitable for the 'emerging research field' (Massaro et al., 2016). We added peer-reviewed journal articles, high-impact conference proceedings, and book chapters to widen the scope of a standard search (De Villiers \& Dumay, 2013).

\subsubsection{Search filters}

The process of the search was carried as follows:

- We peer reviewed journal articles, conference proceedings and book chapters.

- Contributions only in English language were included in SLR

- Subject filters were applied, and only non-technical to semi-technical articles were extracted.

- Finally, no time filters were applied to ensure maximum contributions.

\subsubsection{Search sources}

In order to maximize contributions, no particular journal or database was selected. Instead, it was decided to include all articles published in a recognized peer-reviewed journal or conference proceedings. The search engines included Business Source Complete (EBSCOhost), ProQuest, Google Scholar, Emerald, Scopus, Wiley online database, and Taylor \& Francis.

\subsubsection{Search terms}

To ensure consistency and relevance with the research purpose, we identified following search terms: 'intellectual capital', 'human capital', 'relational capital' and 'structural capital' with either 'big data' or 'big data analytics'.

Intellectual Capital: The value of a firm's personnel knowledge, business training, skills or any data that give the company with an economical advantage is referred as intellectual capital. It is said to be the amount of organizational processes, company's staff skills, and other intangibles that donate to its profits.

Human capital: Human capital refers to each employee's individual expertise, such as experience, professional skills and inventiveness. It is built on intellectual capital, so some e-business model need as much human capital as possible to do its task well.

Relational Capital: The knowledge movement among entities, including as personnel, partners, organizational levels, customers and suppliers, is referred as relational capital.

Structural capital: Organization, relationships and R\&D capitals comprises structural capital. One of the basic intellectual capital components is structural capital, which consists databases, processes and organization's supporting infrastructure that allow human capital to work. It is possessed by a company and remains it even if the employees leave.

\subsection{Cleaning phase}

The cleaning process is explained through a flow chart in Fig. 2 below. Initially, only those papers were selected with "big data" and either of the above phrase in the title, abstract, or keywords included. It helped avoid selecting irrelevant articles (Massaro et al., 2016) 


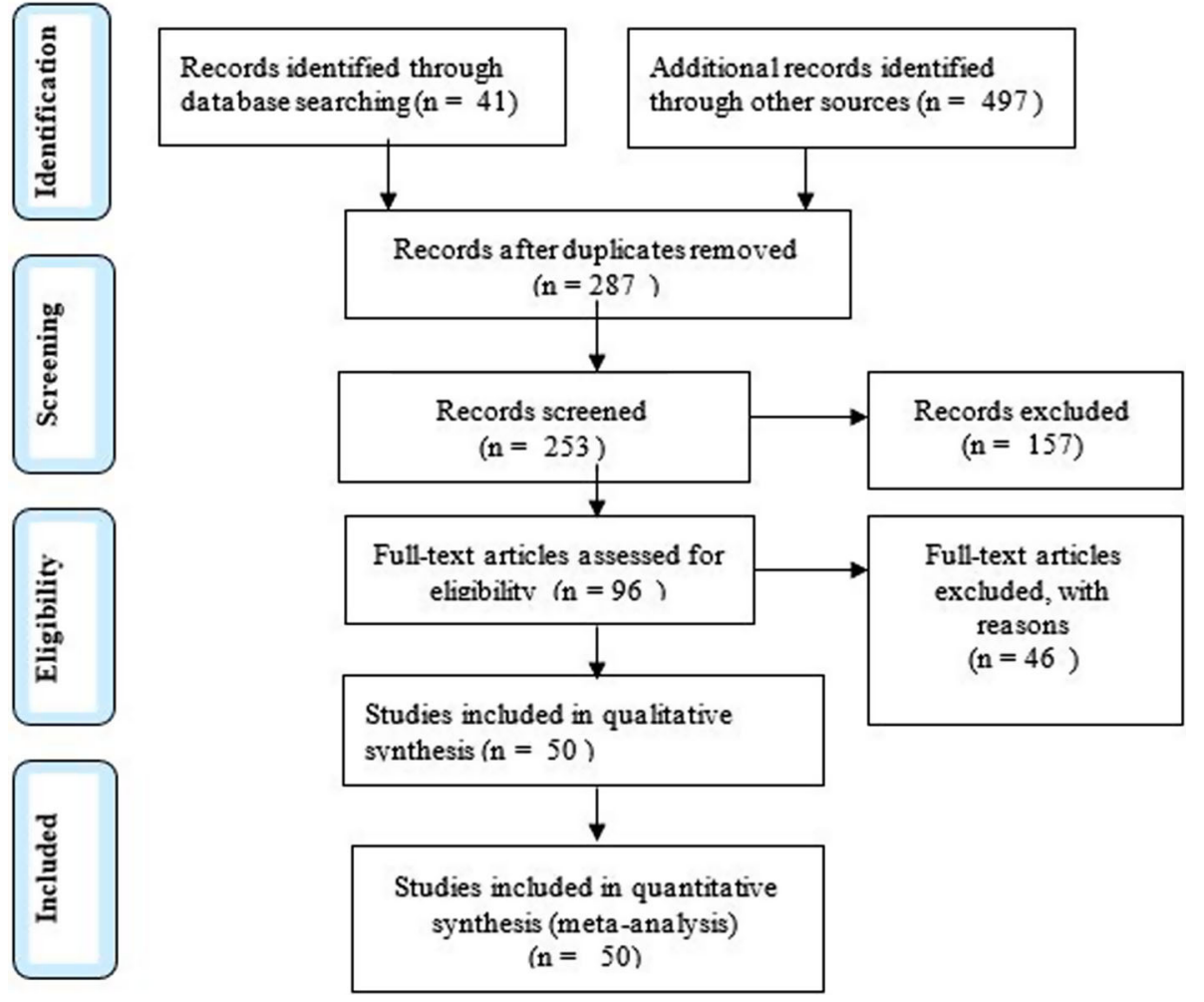

Fig. 2 cleaning phase for SLR

and ensure relevance to the research objective. However, this left us with only 41 articles. Nevertheless, after reading the abstracts, all articles were not usable for being irrelevant or technical and so we had to remove 13 more articles. Therefore, we also searched articles with either one phrase in the abstract and another anywhere in the text. This left us with 497 articles. After removing duplicates, there were 253 articles. After readings abstracts, 157 articles were removed for being beyond the scope of the study. While manually reading the remaining 96 articles, those articles were removed from the analysis, which only used the phrases once or twice in the whole paper. This left us with 50 articles as the final sample to be included in the SLR. Only non-technical articles were included, whereas core articles related to IT and data analytics were excluded.

\subsection{Classification}

Although, no time filter was applied. No prominent research could be found before 2011 on the nexus of BD and IC. The research got its roots mainly since 2013 and reached a maximum in 2018 over the last decade as presented below in Fig. 3.

The citation of these 50 articles is presented below in Table 1 . The citation of the articles was accessed from google scholar. 


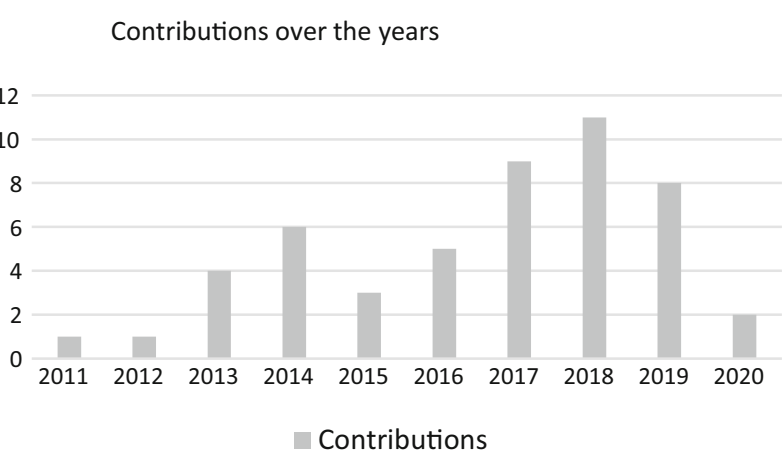

Fig. 3 Analysis of contributions per year (final sample of 50 contributions)

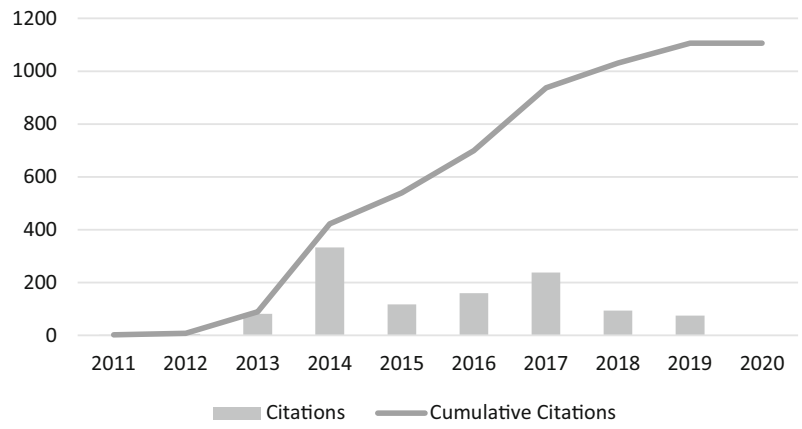

Fig. 4 Frequency of citations (final sample of 50 contributions)

\section{Development of analytical framework}

Out of 96 contributions initially retrieved, 50 articles were finalized after manual reading to develop the analytical framework. To identify and code CI genes (who, what, why, and how), these 50 articles were manually analyzed. Manual coding is recommended to guarantee that an expression's true meaning is conveyed when explaining an idea (Guthrie et al., 2012). Although manual coding is more subject to bias, it is acceptable when the selected literature comes from different sources, scarce and emergent (De Santis \& Presti, 2018). The CI genes related to BD adoption were linked to IC's standard components after we reached a consensus on the analysis, The insights gained were organised into an analytical framework that distinguished between $\mathrm{BD}$ and human capital, BD and relational capital and, BD and structural capital. The analytical framework is presented below in Table 1 and discussed in detail in the next section.

\section{Discussion of findings}

This section discusses the finding of SLR and analytical framework presented above. This analytical framework is developed to identify how BDA and IC co-create value. 
Table 1 Proposed analytical framework

\begin{tabular}{|c|c|c|c|}
\hline & $\begin{array}{l}\text { Big data and human } \\
\text { capital }\end{array}$ & $\begin{array}{l}\text { Big data and relational } \\
\text { capital }\end{array}$ & $\begin{array}{l}\text { Big data and structural } \\
\text { capital }\end{array}$ \\
\hline $\begin{array}{c}\text { What? (Benefits and } \\
\text { opportunities) }\end{array}$ & $\begin{array}{l}\text { Skills improvement } \\
\text { Improved learning } \\
\text { processes } \\
\text { Better } \\
\text { acknowledgment of } \\
\text { employees' needs } \\
\text { Enhanced } \\
\text { Performance } \\
\text { Evaluation } \\
\text { Recruiting policies } \\
\text { discovery } \\
\text { Talent hunting }\end{array}$ & $\begin{array}{l}\text { Improved supply chain } \\
\text { management } \\
\text { Improved networking } \\
\text { with stakeholders } \\
\text { Better customer service } \\
\text { Product personalization } \\
\text { Enhanced customer } \\
\text { segmentation }\end{array}$ & $\begin{array}{l}\text { Increased data volume } \\
\text { Integrated datasets } \\
\text { Data-driven } \\
\text { decision-making } \\
\text { process } \\
\text { Better reporting } \\
\text { Better visualization of } \\
\text { data for decision } \\
\text { making } \\
\text { Transparency }\end{array}$ \\
\hline $\begin{array}{l}\text { What (Threats and } \\
\text { Challenges) }\end{array}$ & $\begin{array}{l}\text { Lack of expertise } \\
\text { Lack of education } \\
\text { and skills } \\
\text { Technology } \\
\text { dependence } \\
\text { Over-reliance on } \\
\text { analytics }\end{array}$ & $\begin{array}{l}\text { Privacy issues } \\
\text { Reputation } \\
\text { Social reviews } \\
\text { irreversible feedback of } \\
\text { customers }\end{array}$ & $\begin{array}{l}\text { Systems' costs } \\
\text { (database, tools, etc.) } \\
\text { Security issues } \\
\text { Data ownership } \\
\text { Reengineering cost } \\
\text { Data quality } \\
\text { Data-driven decision } \\
\text { making }\end{array}$ \\
\hline $\begin{array}{l}\text { Who? (stakeholders, } \\
\text { actors) }\end{array}$ & $\begin{array}{l}\text { Employees, } \\
\text { Employers }\end{array}$ & $\begin{array}{l}\text { Customers, } \\
\text { Competitors, } \\
\text { Suppliers } \\
\text { IT platform }\end{array}$ & $\begin{array}{l}\text { Data sets, } \\
\text { quality of data sets, } \\
\text { the volume of data } \\
\text { Infrastrucutre }\end{array}$ \\
\hline $\begin{array}{l}\text { How? (skills and } \\
\text { capabilities) }\end{array}$ & $\begin{array}{l}\text { IT Capabilities } \\
\text { Automation-savy } \\
\text { Technical and soft } \\
\text { skills } \\
\text { analytical } \\
\text { dynamic capability } \\
\text { adaptability } \\
\text { Knowledge } \\
\text { Management }\end{array}$ & $\begin{array}{l}\text { social-media skillfulness } \\
\text { Value creation } \\
\text { capabilities } \\
\text { Network capabilities }\end{array}$ & $\begin{array}{l}\text { Resource Allocation } \\
\text { Dynamic Capability } \\
\text { Innovation } \\
\text { Cybersecurity } \\
\text { capabilities } \\
\text { Infrastructure } \\
\text { sophistication } \\
\text { SC sustainability }\end{array}$ \\
\hline Why? Value creation & $\begin{array}{l}\text { enhanced learning } \\
\text { organizational } \\
\text { growth } \\
\text { informed decision } \\
\text { making } \\
\text { sustainability }\end{array}$ & $\begin{array}{l}\text { Value to customers } \\
\text { benefits to customers } \\
\text { value to society } \\
\text { sustainability }\end{array}$ & $\begin{array}{l}\text { Financial performance } \\
\text { Competitiveness } \\
\text { real-time solution } \\
\text { reliability } \\
\text { Sustainability }\end{array}$ \\
\hline
\end{tabular}

Big data refers to high volume, high-velocity and high-variety data (Laney, 2001). Since data does not hold any value to the organizations itself, it needs analytics to extract value. Big data analytics refers to the ability of organizations to collect and analyse massive amounts of data (e.g., text, audio, picture, videos) from many sources (e.g., social media, websites, sensors) to gain useful insights about people (Persaud \& Schillo, 2017). BDA offer various benefits to the incumbents which include business and economic value (La Torre et al., 2018a, 2018b), collaborative innovation (Silva \& Ma, 2017), competitive growth strategy and improved talent engagement (Chaturvedi, 2016), enhanced productivity (D'Souze \& William, 2017), health surveillance (Pastorino et al., 2019); supply chain management (Gupta 
et al., 2019), disaster management (Akter \& Wamba, 2019); innovation (Babu et al., 2021); Humanitarian-relief programs (Nagendra et al., 2020).

\subsection{The nexus between human capital and big data}

Human capital remains one of the most precious assets of an organization even in the presence of big data (Higgins, 2014; Mikalef et al., 2019; O’Mahony, 2015; Welbourne, 2015). Mainly, it is the human capital that helps organizations convert their assets and resources into value. With the advent of HR analytics many productive tools are available for organizations to make informed decisions of hiring 'the right talent' (Thakur, 2017; Gould, 2015; O'Mahony, 2015). Also, big data offers a range of opportunities within performance measurement systems and automation of processes (Davenport, 2014) along with enhanced innovation that combines intellectual and physical capital (Karlik et al., 2019).

The method of determining whether a part of text (tweet, product review, etc.) is good, bad, or unbiased is known as sentiment analysis. It employs features such as emotion, tone, context and others to regulate a client's approach concerning a product. The approach is based on NLP and ML algorithms that categorize writing pieces and employs variety of algorithms. It is often known as opinion mining and a commonly used yet frequently misinterpreted term. It determine the emotional tone underlying a succession of words, which is used to acquire a better considerate of feelings, opinions and attitudes. The scope and usage of data analytics is increasing across the globe (Gul \& Ellahi, 2021; Moustaghfir \& Schiuma, 2013; Mayer-Schönberger \& Cukier, 2013; Boyd \& Crawfold, 2012). Since sentiment analysis can help investigate the relationship between big data and intelligence (Landon-Murray, 2016), Roberts-Mahoney and Means (2016) find that BD and adaptive learning systems are redefining educational policies in the US as BDA (Big Data Analytics) makes teaching transfer possible. Pakistan has been using BDA for good governance and government power in the country since early 2000 at a national level (Gul \& Ahsan, 2019) and data analytics for banking sector (Gul \& Ellahi, 2021).

$\mathrm{BD}$ is also helpful in identifying the reasons behind unemployment and expert profiling (Silva \& Ma, 2017). Such analytics also offer capability to understand senior management's expectations and diagnose their workforce's strengths and challenges (Brock, 2017; Ling et al., 2014). Big data also offers specialized algorithm including linear regression, logistic regression and K-means clustering to predict 'retention rate' of employees (Vereckey, 2013) which help firms figure out their employee's commitment intensity and their intention to quit. When this is known, managers will have a better idea of how employee's career development needs to be turned and the companies' resources will not be wasted on those employees who intend to leave (Howes, 2014; Vereckey, 2013; Wei et al., 2015).

BDA is still not a mature field, neither at an organizational level nor at an educational level. It comes up with numerous challenges including procurement lags, data stove piping, poor visualization of data, data quality, and security (Landon-Murray, 2016). Human capital has a significant impact in the susceptibility of an organisation due to behavioural and human variables. Moreover, the lack of expertise in human capital's required skills and abilities makes it hard for the incumbents to reap the promised benefits fully (La Torre, 2018a, 2018b; Welbounre, 2015) as the complexity of BD analytics challenges the workforce to be more skilled and dynamic (Karlik et al., 2019). Besides, digitalization drives massive changes at work place including the workforce across all industries worldwide (Florea et al., 2017). Other challenges include poor data quality (La Toree, b) and poor visualization of data that may lead to misunderstanding and poor decision making for non-IT employees (Ladeau et al., 
2017). Today, human capital is expected much more than they can offer in reality (Tian 2017; Chaturvedi, 2016; Erickson \& Rothberg 2015; Welbounre, 2015) and HC needs to possess certain skills such as analytical and dynamic capabilities (Sahlin \& Angelis, 2019), internal capabilities (La Torre, b), and innovative organizational capabilities (Micheli \& Mura, 2017).

Evidently, humans are essential factors in the process of big data and human capital collaboration (La Torre, 2018a, 2018b; D’Souze \& William, 2017; Chaturvedi, 2016; Debortoli et al., 2014). Various HC related analytics have been produced to help companies improve their performance and create value. ${ }^{1}$ The development of well-trained and skilled employees with informed decision making is the significant contribution of interaction between HC and BD (Sahlin \& Angelis, 2019; Secundo et al., 2017; Welbounre, 2015; Davenport, 2014). Other contributions include business and economic value (La Torre et al., 2018a, 2018b), collaborative innovation (Silva \& Ma, 2017), competitive growth strategy and improved talent engagement (Chaturvedi, 2016), productivity (D’Souze \& William, 2017), health surveillance (Pastorino et al., 2019) and personalized learning (Roberts-Mahoney \& Means, 2016).

\subsection{The nexus between structural capital and big data}

Human capital gives rise to structural capital, which combines knowledge and intangible assets acquired from an organization's operations. Employees require these processes and structures to be productive, but structural capital still survives when employees leave (van Caenegem, 2002). Seminal work by Bontis (1998) define structural capital as 'enduring knowledge existing within the organization' such as protocols and structures, corporate culture, systems and routines.

With the emergence of BD and machine learning, information ecosystems are widening. The ecological concepts application to modelling the information society is known as information ecology. It deliberates the features and dynamics of digital informational environment, which is becoming increasingly complicated, dense and important. It responsible for regulating important ecological processes, ensuring stability and supporting life schemes. Among various benefits associated with $\mathrm{BD}$ and $\mathrm{SC}$ interaction, the significant contribution is the access to a large amount of data which can be accessed, analysed and used in decision making (Wamba et al., 2015). Big data manage structural capital to ensure timely and appropriate data availability for strategic decisions. (Ratia, 2019). Along with that, organizations that hope to find opportunities such as altering their operations, innovating their markets, and effectively serving their customers can invest in BDA for further value creation (Ratten, 2020; Brown et al., 2011).

Having access to an extensive and large amount of data has its advantages but companies need to distinguish between relevant and irrelevant data which is challenging too. Some companies wrongly believe that data volume adds to the data quality meaning more data resulting in better quality, but this concept is wrong (Kaisler et al., 2013) as 'it is easier to get the data in than out' (Jacobs, 2009, p. 8). Moreover, the value creation depends largely on data quality (Schroeck et al., 2012). Data volume and data velocity, problems related to data ownership and data security are also associated with big data (McGuire \& Ladd, 2014). Since vast amounts of data is scattered across many internal and external sources, it gives rise to skepticism (Kaisler et al., 2013).

\footnotetext{
1 For example: workforce analytics helps human capital to create value for the organization and other stakeholders (La Torre, 2018; Brock, 2017), talent analytics uses predictive and prescriptive analytics to explore required latent (Chaturvedi, 2016) and learning analytics to improve employees' learning (Roberts-Mahoney \& Means, 2016; Welbounre, 2015).
} 
Since big data is mostly unstructured and may not fit well with existing models, it may call for significant alternation or replacement of existing models and tools (Davenport, 2014; Sahlin \& Angelis, 2019). The pace of change and developments in products, services, and processes challenge the traditional linear business environment and necessitates faster responses to competitors' moves and actions (Mithas et al., 2013; Sahlin \& Angelis, 2019). New rules would rapidly be abandoned if they do not align with the past practices and if the connections between existing rules and routines are strong (van der Steen, 2009). Collaboration among IT and non-IT employees on competencies, procedures, and processes for improved organizational performance is aimed (Secundo et al., 2017; Batra, 2014; Mulgan, 2012).

\subsection{The nexus between relational capital and big data}

Strictly defined, knowledge embedded in customer relationships and marketing channels while conducting business is called Relational Capital (Bontis, 1998). However, when broadly defined, organizational relationships embedded in all stakeholders, including suppliers, competitors, governments, and regulating authorities other than brands, reputation, and trademarks are RC (Cuganesan, 2005). The ability to share knowledge and skills in real-time is one of the significant advantages of complementarity of relational capital and big data recently observed in China during Covid-19 (Gravili et al., 2020). On the other hand, the lack of such technically advanced equipment in intensive care made Italy a vulnerable example during the pandemic.

Relational capital managed with big data analytics improves data sharing with stakeholders and strengthens relationships with them (Ratia, 2019). Notably, data analytics practitioners emphasize that most of the companies are not aware of the totality of their data and instead of typical inside information systems, most of this data is located outside of organization (McGuire \& Ladd, 2014). However, thanks to the advent of advanced analytics, companies can integrate data from multiple sources to gain a competitive advantage, create knowledge (La Torre, 2018a, b) and build HC through teamwork (Kitchin \& McArdle, 2016; Wang \& Cotton, 2018). Besides, the digital relational capital has become a crucial performance driver in today's digitalization and internet era (Fredriksson, 2015; Hirsch, 2013; Molodchik et al., 2018).

When organizations plow money into newer technologies to homogenize different data sets to make information gathering more efficacious, they have to be careful of the adjoining risks. A threat to a company's or entity's good name or position is known as reputational risk. Reputational risk can manifest itself in a variety of ways, directly as an effect of the company's actions. Indirectly, as an effect of the acts of employees. Reputational risk relates to the possibility that public perception, negative publicity, and uncontrollable measures will harm a business's reputation, resulting in revenue loss. It hits unpredictably and changes the picture of business. Therefore, companies have to develop both information-gathering capabilities and processes to enhance consolidation as if data is stolen or disclosed by concerned or unconcerned parties, the loss of privacy occurs, and it causes serious reputational risk for the organizations (Casado-Molina et al., 2019; Fan \& Bifet, 2013; Ndou et al., 2018).

The worth of an organization's interior and exterior social interactions is known as relational capital. Relational capital is the value created by a library's ties with its external environment, including consumers, investors, providers and other libraries or organizations. Digital RC plays a crucial role in enhancing organizational' performance through website development and communication (Molodchik et al., 2018). Successful deployment of big data within relational capital management is possible through websites and social media 
management (Molodchik et al., 2018; Ratia et al., 2018). The analyzing process of social media viewers and evolving an approach tailored to them, distributing and creating content for social media outlines, cooperating with influencers, measuring, reporting and monitoring social media performance, observing operational conversations, ROI and giving community service are the examples of social media management. Since the website's role is significant in driving organization's financial and non-financial performance, the company may hire or outsource social media experts, web developer, etc.

Digital RC plays a crucial role in enhancing organizational' performance through website development and communication (Molodchik et al., 2018). Successful deployment of big data within relational capital management is possible through websites and social media management (Molodchik et al., 2018; Ratia et al., 2018). Social media management is the process of managing organizations' online presence through social media platforms (Van Looy, 2016) Since the website's role is significant in driving organization's financial and non-financial performance, the company may hire or outsource social media experts, web developer, etc.

The relationships built with customers, suppliers, and other organizations are called 'networks' (Möller et al., 2005), which are the prime source of value creation in the presence of big data. A famous quote, 'no business is an island' by Håkansson and Snehota (1989), validates networks' role in today's complex, digital and dynamic business world. Consequently, strong network is a promise to sustainable value creation (Harlow, 2018). When an organization uses its time and resources to develop some kind value that is then delivered to a client base, is known as value creation. As a result, the company profits from what it has built. To optimize total value, sustainable value creation needs intellectual capital. It is important to gain a deeper understanding of how businesses may increase long-term value development.

\section{Concluding remarks}

This study responds to the call to examine how big data can enhance the organizational value created through IC. The aim of this study is to explore how BD creates value when interacts with IC. The proposed analytical framework based on the collective intelligence approach and SLR of $\mathrm{N}=50$ has built the complementarity of big data and IC components in detail. This framework can be used by organizations as a guide before, during, and after adopting BD in building realistic expectations of their investment. The model is self-explanatory; it may help companies map out the role of different actors in the process. The model highlights the common threats and opportunities, which will allow companies to know exactly what to expect when big data interacts with human capital, relational capital, and structural capital. There will be no blame game in case of unsuccessful BDA investment, as this framework will help identify "who is responsible for what." Another vital contribution of the analytical framework is identifying the skills and capabilities required to deploy BD and its interaction with IC components successfully. Knowing about desired skills and capabilities, it would be possible for the incumbents to hire, train, and transform employees into the "right skill set." The study posits that data remains a valuable asset as long as it ensures quality, transparency, and security. However, that data needs to be well communicated and understood for efficacious relationship building as a result of BD adoption. Finally, unlearning old practices and routines is as vital as learning new methods and procedures. Findings suggest the human 
capital scope has changed largely as per the employee expectations much more than in the past with strong dynamic, technical, analytical and IT capabilities.

\subsection{Limitations}

Since this research is exploratory, it will offer opportunities for refinement in the future. Despite a rigorous effort made to include maximum SLR contributions, constraints related to time, language, and scope made it difficult to include each article in the study that deals with BD and IC interaction. Another limitation of the study is the manual coding of the contributions, although literature supports manual coding when the literature is scarce and comes from varied sources (Guthrie et al., 2012). Due to the selection of literature to be included in any literature review, including SLR at the discretion of the research, all review studies are biased.

\subsection{Implications and future research}

This study contributes to the existing literature and explains the complementarity of BD and IC and how they co-create value in an organization. Within the preliminary stage of connecting BD with IC components, this study offers new insights for IC research in the age of big data.

This study makes multiple contributions both from theoretical and practical perspectives. This paper offers a more in-depth insight into BD investment and IC management's complementarity from a value creation perspective. This study is one of the very few studies which incorporate a collective intelligence approach to investigate the interaction of knowledge assets and how they co-create value for organizations and societies. The paper will also add to the information systems literature to provide insights on how BD co-creates value when interacts with IC components. This research will facilitate future research and understanding of how these intangible knowledge assets affects an organization's value creation process.

From a practical viewpoint, this study is one of the pioneer studies which provide a holistic overview of threat and opportunities related to BDA and its interaction with IC. The study also identifies the skills and capabilities required to successfully deploy BD and effectively manage IC from a value creation perspective. Thus, the proposed analytical framework will help practitioners and potential investors make real expectations related to BDA adoption. The firms will map out the required skills and look for those skills while hiring new employees or planning training programs for them.

Based on a structured literature review conducted in this study, it is evident that most of the previous literature focused on how big data affects human capital, whereas how big data affects relational and structural capital is largely unexplored. Thus, we call for future empirical studies to investigate the following sub-questions under the main research question of; what is the future for the research on the complementarity of $B D \& I C$ ?

RQ1: How does big data help to build a 'network' and strengthen relational capital?

RQ2: How does the structural capital create value through learning new routines, processes, and procedures of conducting business in the presence of big data?

RQ3: How does big data's interaction with human capital facilitate data visualization and aid data-driven decision making?

RQ4: How do big data related privacy issues and security problems affect IC?

RQ5: What are the skills and capabilities related to BD and IC, which affect a firm's performance through constructs building for survey-based studies? 
RQ6: What are the threats and challenges associated with the knowledge waste if big data and intellectual capital are not managed well.

\section{References}

Akter, S., \& Wamba, S. F. (2019). Big data and disaster management: A systematic review and agenda for future research. Annals of Operations Research, 283(1), 939-959.

Babu, M. M., Rahman, M., Alam, A., \& Dey, B. L. (2021). Exploring big data-driveninnovation in the manufacturing sector: Evidence from UK firms. Annals of Operations Research, 1-28.

Barón, M. J., López, J. F., Montenegro-Marin, C. E., \& García, P. A. (2018). Design of a Computational Model for Organizational Learning in Research and Development Centers (R\&D). Advances in Artificial Intelligence-IBERAMIA 2018 Lecture Notes in Computer Science, 495-506. https://doi.org/10.1007/ 978-3-030-03928-8_40

Batra, S. (2014). Big data analytics and its reflections on DIKW hierarchy. Review of Management, 4(1/2), 5.

Bontis, N. (1998). Intellectual capital: An exploratory study that develops measures and models. Managementdecision, 36(2), 63-76.

Boyd, D., \& Crawford, K. (2012). Critical questions for big data: Provocations for a cultural, technological, and scholarly phenomenon. Information, Communication \& Society, 15(5), 662-679.

Brock, T. R. (2017). Performance analytics: The missing big data link between learning analytics and business analytics. Performance Improvement, 56(7), 6-16.

Brown, B., Chui, M., \& Manyika, J. (2011). Are you ready for the era of 'big data.' McKinsey Quarterly, 4(1), $24-35$.

Casado-Molina, A.-M., Ramos, C. M., Rojas-de-Gracia, M.-M., \& Sánchez, J. I. P. (2019). Reputational intelligence: Innovating brand management through social media data. Industrial Management \& Data Systems, 120(1), 40-56.

Chaturvedi, V. (2016). Talent analytics as an indispensable tool and an emerging facet of HR for organization building. FIIB Business Review, 5(3), 13-20.

Cuganesan, S. (2005). Intellectual capital-in-action and value creation: a case study of knowledge transformations in an innovation project. Journal of Intellectual Capital, 6(3), 357-373.

Davenport, T. H. (2014). How strategists use "big data" to support internal business decisions, discovery and production. Strategy \& Leadership.

De Santis, F., \& Presti, C. (2018). The relationship between intellectual capital and big data: A review. Meditari Accountancy Research, 26(3), 361-380.

De Villiers, C., \& Dumay, J. (2013). Construction of research articles in the leading interdisciplinary accounting journals. Accounting, Auditing \& Accountability Journal, 26(6), 876-910.

Debortoli, S., Müller, O., \& vom Brocke, J. (2014). Comparing business intelligence and big data skills. Business \& Information Systems Engineering, 6(5), 289-300.

Dixon-Woods, M. (2011). Using framework-based synthesis for conducting reviews of qualitative studies. BMC Medicine, 9(1), 1-2.

D'souza, C., \& Williams, D. (2017). The digital economy. Bank of Canada Review, 2017(Spring), 5-18.

Erickson, S., \& Rothberg, H. (2015). Big data and knowledge management: Establishing a conceptual foundation. Leading Issues in Knowledge Management, 2, 204.

Fan, W., \& Bifet, A. (2013). Mining big data: Current status, and forecast to the future. ACM SIGKDD Explorations Newsletter, 14(2), 1-5.

Florea, A., Kifor, C., Nicolaescu, S., Cocan, N., \& Receu, I. (2017). Intellectual Capital Evaluation and Exploitation Model Based on Big Data Technologies. Economic and Social Development (Book of Proceedings). In: 24th International Scientific Conference on Economic and Social.

Fredriksson, C. (2015). Knowledge management with Big Data Creating new possibilities for organizations. In: The XXIVth Nordic Local Government Research Conference (NORKOM),

Galiveeti, S., Tawalbeh, L., Tawalbeh, M., \& El-Latif, A. A. (2021). Cybersecurity Analysis: Investigating the Data Integrity and Privacy in AWS and Azure Cloud Platforms. Studies in Big Data Artificial Intelligence and Blockchain for Future Cybersecurity Applications. https://doi.org/10.1007/978-3-030-74575-2_17

Gandomi, A., \& Haider, M. (2015). Beyond the hype: Big data concepts, methods, and analytics. International Journal of Information Management, 35(2), 137-144.

Gao, J., Wang, H., \& Shen, H. (2020). Task Failure Prediction in Cloud Data Centers Using Deep Learning. IEEE Transactions on Services Computing. https://doi.org/10.1109/tsc.2020.2993728

Gould, D. (2015). Where talent and tech meet. Bloomberg Businessweek, No. 4425, pp. S1-S6. 
Gravili, G., Manta, F., Cristofaro, C. L., Reina, R., \& Toma, P. (2020). Value that matters: Intellectual capital and big data to assess performance in healthcare. An empirical analysis on the European context. Journal of Intellectual Capital, 22(2), 260-289.

Gul, R., \& Ahsan, A. (2019). Big Data and Analytics: Case Study of Good Governance and Government Power. In: European Conference on Intangibles and Intellectual Capital.

Gul, R., \& Ellahi, N. (2021). The nexus between data analytics and firm performance. Cogent Business \& Management, 8(1), 1923360.

Gupta, S., Altay, N., \& Luo, Z. (2019). Big data in humanitarian supply chain management: A review and further research directions. Annals of Operations Research, 283(1), 1153-1173.

Guthrie, J., Ricceri, F., \& Dumay, J. (2012). Reflections and projections: A decade of intellectual capital accounting research. The British Accounting Review, 44(2), 68-82.

Håkansson, H., \& Snehota, I. (1989). No business is an island: The network concept of business strategy. Scandinavian Journal of Management, 5(3), 187-200.

Harlow, H. (2018, September). Ethical concerns of artificial intelligence, big data and data analytics. In European Conference on Knowledge Management (pp. 316-323). Academic Conferences International Limited.

Higgins, J. (2014). Bringing HR and finance together with analytics. Workforce Solutions Review, 5(2), 11-13.

Hiremath, P. N., Armentrout, J., Vu, S., Nguyen, T. N., Minh, Q. T., \& Phung, P. H. (2019). MyWebGuard: Toward a User-Oriented Tool for Security and Privacy Protection on the Web. In T. Dang, J. Küng, M. Takizawa, \& S. Bui (Eds.), Future Data and Security Engineering FDSE 2019. Lecture Notes in Computer Science. (Vol. 11814). Cham: Springer.

Hirsch, P. B. (2013). Corporate reputation in the age of data nudity. Journal of Business Strategy, 34(6), 36-39.

Howes, J. (2014). Taking a long data view for effective workforce analytics. Workforce Solutions Review, 5(2), $5-8$.

Jacobs, A. (2009). The Pathologies of Big Data. Communications of the ACM, 52(8), 10.

Kaisler, S., Armour, F., Espinosa, J. A., \& Money, W. (2013). Big data: Issues and challenges moving forward. In: 2013 46th Hawaii international conference on system sciences,

Karlik, A. E., Platonov, V. V., \& Krechko, S. A. (2019). Organizational support for the digital transformation of cooperation networks and the implementation of cyber+ social systems. St. Petersburg State Polytechnical University Journal Economics, 12(5), 9.

Kitchin, R., \& McArdle, G. (2016). What makes Big Data, Big Data? Exploring the ontological characteristics of 26 datasets. Big Data \& Society, 3(1), 2053951716631130.

La Torre, M., Botes, V. L., Dumay, J., Rea, M. A., \& Odendaal, E. (2018a). The fall and rise of intellectual capital accounting: New prospects from the Big Data revolution. Meditari Accountancy Research, 26(3), 381-399.

La Torre, M., Dumay, J., \& Rea, M. A. (2018b). Breaching intellectual capital: Critical reflections on Big Data security. Meditari Accountancy Research, 26(3), 463-482.

LaDeau, S., Han, B., Rosi-Marshall, E., \& Weathers, K. (2017). The next decade of big data in ecosystem science. Ecosystems, 20(2), 274-283.

Landon-Murray, M. (2016). Big data and intelligence: Applications, human capital, and education. Journal of Strategic Security, 9(2), 92-121.

Laney, D. (2001). 3D data management: Controlling data volume, velocity and variety. META Group Research Note, 6(70), 1 .

Lévy, P. (1994). L'intelligence collective. La Découverte, París: Pour une anthropologie du cyberespace.

Ling, Z. J., Tran, Q. T., Fan, J., Koh, G. C., Nguyen, T., Tan, C. S., et al. (2014). GEMINI: An integrative healthcare analytics system. Proceedings of the VLDB Endowment, 7(13), 1766-1771.

Malone, T. W., Atlee, T., \& Lévy, P. (2008). Collective intelligence. Social Text, available at http://www. Socialtext.Netlmit-cci-hcilindexcgi.

Malone, T. W., Laubacher, R., \& Dellarocas, C. (2010). The collective intelligence genome. MIT Sloan Management Review, 51(3), 21.

Martin-Moncunill, D., Gaona-García, P. A., Gordillo-Orjuela, K., \& Montenegro-Marin, C. E. (2016). User Experiences in Virtual Reality Environments Navigation Based on Simple Knowledge Organization Systems. Communications in Computer and Information Science Applied Computer Sciences in Engineering. https://doi.org/10.1007/978-3-319-50880-1_4

Massaro, M., Dumay, J., \& Guthrie, J. (2016). On the shoulders of giants: Undertaking a structured literature review in accounting. Accounting, Auditing \& Accountability Journal, 29(5), 767-801.

Mayer-Schönberger, V., \& Cukier, K. (2013). Big data: A revolution that will transform how we live, work, and think. Houghton Mifflin Harcourt.

McGuire, S., \& Ladd, B. (2014). BD and human capital management. Workforce Solutions Review, 5(2), 2. 
Micheli, P., \& Mura, M. (2017). Executing strategy through comprehensive performance measurement systems. International Journal of Operations \& Production Management.

Mikalef, P., Boura, M., Lekakos, G., \& Krogstie, J. (2019). Big data analytics and firm performance: Findings from a mixed-method approach. Journal of Business Research, 98, 261-276.

Mithas, S., Lee, M. R., Earley, S., Murugesan, S., \& Djavanshir, R. (2013). Leveraging big data and business analytics [Guest editors' introduction]. IT Professional, 15(6), 18-20.

Möller, K., Rajala, A., \& Svahn, S. (2005). Strategic business nets-their type and management. Journal of Business Research, 58(9), 1274-1284.

Molodchik, M., Paklina, S., \& Parshakov, P. (2018). Digital relational capital of a company. Meditari Accountancy Research, 26(3), 443-462.

Moustaghfir, K., \& Schiuma, G. (2013). Knowledge, learning, and innovation: research and perspectives. Journal of Knowledge Management, 17(4), 495-510.

Mulgan, G. (2012). The theoretical foundations of social innovation. In Social innovation (pp. 33-65). London: Palgrave Macmillan.

Nagendra, N. P., Narayanamurthy, G., \& Moser, R. (2020). Management of humanitarianrelief operations using satellite big data analytics: The case of Kerala floods. Annals of Operations Research, 1-26.

Ndou, V., Secundo, G., Dumay, J., \& Gjevori, E. (2018). Understanding intellectual capital disclosure in online media Big Data. Meditari Accountancy Research, 26(3), 499-530.

O’Mahony, J. (2015). What's next for human resources. Bloomberg Businessweek, 4438, 1.

Pastorino, R., De Vito, C., Migliara, G., Glocker, K., Binenbaum, I., Ricciardi, W., \& Boccia, S. (2019). Benefits and challenges of Big Data in healthcare: an overview of the European initiatives. European Journal of Public Health, 29(Supplement_3), 23-27.

Persaud, A., \& Schillo, S. R. (2017). Purchasing organic products: Role of social context and consumer innovativeness. Marketing Intelligence \& Planning, 35(1), 130-146.

Ratia, M., Myllärniemi, J., \& Helander, N. (2018). The new era of business intelligence. Meditari Accountancy Research, 26(3), 531-546.

Ratia, M., Myllärniemi, J., \& Helander, N. (2019). The potential beyond IC 4.0: The evolution of business intelligence towards advanced business analytics. Measuring Business Excellence, 23(4), 396-410.

Ratten, V. (2020). Cloud computing technology innovation advances: a set of research propositions. In M. Khosrow-Pour (Ed.), Disruptive Technology: Concepts, Methodologies, Tools, and Applications (pp. 693-703). IGI Global.

Roberts-Mahoney, H., Means, A. J., \& Garrison, M. J. (2016). Netflixing human capital development: Personalized learning technology and the corporatization of K-12 education. Journal of Education Policy, 31(4), 405-420.

Sahlin, J., \& Angelis, J. (2019). Performance management systems: Reviewing the rise of dynamics and digitalization. Cogent Business \& Management, 6(1), 1642293.

Schroeck, M., Shockley, R., Smart, J., Romero-Morales, D., \& Tufano, P. (2012). Analytics: The real-world use of big data. IBM Global Business Services, 12(2012), 1-20.

Secundo, G., Del Vecchio, P., Dumay, J., \& Passiante, G. (2017). Intellectual capital in the age of Big Data: Establishing a research agenda. Journal of Intellectual Capital, 18(2), 242-261.

Secundo, G., Dumay, J., Schiuma, G., \& Passiante, G. (2016). Managing intellectual capital through a collective intelligence approach. Journal of Intellectual Capital, 17(2), 298-319.

Silva, T., \& Ma, J. (2017). Expert profiling for collaborative innovation: Big data perspective. Information Discovery and Delivery.

Thakur, S. J. (2017). Jean Paul Isson and Jesse S. Harriott. People analytics in the era of big data: Changing the way you attract, acquire, develop, and retain talent. Hoboken, NJ: Wiley, 2016, 416 pages, \$49.95, hardcover. Personnel Psychology, 70(4), 929-930.

Tian, X. (2017). Big data and knowledge management: A case of déjà vu or back to the future? Journal of Knowledge Management, 21(1), 113-131.

Uden, L., \& Del Vecchio, P. (2018). Transforming the stakeholders' Big Data for intellectual capital management. Meditari Accountancy Research, 26(3), 420-442.

Van Caenegem, W. (2002). Intellectual property and intellectual capital. Intellectual Property, 3, 1-2002.

Van der Steen, M. (2009). Inertia and management accounting change. Accounting, Auditing \& Accountability Journal, 22(5), 736-761.

Van Looy, A. (2016). Social media management. Springer International Publishing Switzerland 2016.

Vereckey, B. (2013). The talent within. Bloomberg Businessweek, 4328, 3.

Wamba, S. F., Akter, S., Edwards, A., Chopin, G., \& Gnanzou, D. (2015). How 'big data' can make big impact: Findings from a systematic review and a longitudinal case study. International Journal of Production Economics, 165, 234-246. 
Wang, L., \& Cotton, R. (2018). Beyond Moneyball to social capital inside and out: The value of differentiated workforce experience ties to performance. Human Resource Management, 57(3), 761-780.

Wei, D., Varshney, K. R., \& Wagman, M. (2015). Optigrow: People analytics for job transfers. In: 2015 IEEE International Congress on Big Data,

Welbourne, T. M. (2015). Data-Driven Storytelling: The Missing Link in HR Data Analytics. Employment Relations Today, 41(4), 27-33.

Publisher's Note Springer Nature remains neutral with regard to jurisdictional claims in published maps and institutional affiliations. 